\title{
Examining the Reggio Emilia Approach: Keys to Understanding Why it Motivates Students
}

\author{
Alexa Fraley Gardner ${ }^{1}$ \& Brett D. Jones ${ }^{2}$ \\ ${ }^{1}$ Child Development Center, Virginia Tech, Blacksburg \\ ${ }^{2}$ School of Education, Virginia Tech, Blacksburg
}

USA

Correspondence: Alexa Fraley Gardner. 140D Wallace Hall, 295 West Campus Drive, Blacksburg, VA 24061. USA. E-mail: alfraley@vt.edu

(C) Education \& Psychology I+D+i and Ilustre Colegio Oficial de la Psicología de Andalucía Oriental (Spain) 


\begin{abstract}
Because of the success of the Reggio Emilia Approach in early childhood education, it could be useful to researchers and practitioners to identify and explicate components of the approach that make it effective in motivating students. In this paper, we examine the Reggio Emilia Approach through the lens of the MUSIC ${ }^{\circledR}$ Model of Motivation, a model based on key motivation components (i.e., empowerment, usefulness, success, interest, and caring) derived from current research and theory. We explain the connections between the Reggio approach and the MUSIC model using theoretical and practical examples to demonstrate that the success of the Reggio approach is in part due to the manner in which it is consistent with key motivation principles. We believe that educators could assess their own programs to determine whether they could do more to incorporate these motivational components into their educational environment.
\end{abstract}

Keywords: Reggio Emilia, motivation, social-constructivism, MUSIC Model of Motivation 


\section{Resumen}

Debido al éxito de la propuesta Reggio Emilia en la educación de la infancia temprana, tanto para investigadores como practicantes sería útil identificar y explicar qué componentes de dicha propuesta la hacen efectiva para motivar a los estudiantes. En este artículo, examinamos la propuesta Reggio Emilia a través de la lente del modelo de motivación $M U S I C^{\circledR}$, un modelo basado en cinco componentes motivacionales claves (empoderamiento, utilidad, éxito, interés y cuidado) producto de teorías e investigaciones actuales. Explicamos las conexiones entre la propuesta Reggio y el modelo MUSIC usando ejemplos teóricos y prácticos que demuestran que el éxito de la propuesta Reggio es debido en parte a su consistencia con los principios motivacionales claves. Creemos que los educadores pueden evaluar sus propios programas para determinar si pueden incorporar mejor estos componentes motivacionales en su ambiente educativo.

Palabras Clave: Reggio Emilia, motivación, constructivismo social, modelo de motivación MUSIC. 


\section{Introduction}

The Reggio Emilia Approach began in the preprimary schools in Reggio, Italy but has since influenced the philosophies of early childhood educators across the globe. The major foundational components of the Reggio Emilia approach include: a focus on the child as an active part of the learning process; a strong respect for the child's role in his or her own learning process; the importance of the environment in learning; the value placed on teacher reflection, documentation, and research; the use of a curriculum guided foremost by the interests of the children and then framed by the expertise of the teacher; the role of community as related to children's learning; and a focus on socially-based project work as key to children achieving deeper conceptual understandings. Teachers from around the world travel to Reggio to tour their schools; and many schools, in a variety of cultures, implement practices inspired by the schools of Reggio within their own school context (Edwards, Gandini, \& Forman, 1998, p. 5).

Given the high level of interest in the Reggio Emilia Approach and the apparent success of the Reggio schools, it could be useful to researchers and practitioners to identify and explicate components of the Reggio approach that make it effective in motivating students. The purpose of this paper is to do that by examining the Reggio Emilia Approach through the lens of current motivation research and theory. We believe that the success of the Reggio approach is not happenstance, but rather, it is due to the manner in which the approach integrates tried and true motivation principles. As a result, we believe that other early childhood programs could learn from and incorporate these motivational principles in an effort to increase the quality of the educational environment, regardless of whether or not the overall program is completely consistent with the Reggio Emilia Approach.

In this article, we compare the Reggio Emilia Approach to the principles included in the MUSIC ${ }^{\circledR}$ Model of Motivation (MUSIC model; Jones, 2009, 2010a, 2015) because this model was developed based on current research and theories in the field of motivation. Five key principles of the model are that students are more motivated when they perceive that: (1) they are eMpowered, (2) the content is Useful, (3) they can be Successful, (4) they are Interested, and (5) they feel Cared for by others in the learning environment (see www.theMUSICmodel.com). The name of the model (MUSIC) is an acronym based on these 
five principles. Although the ideas in the MUSIC model have been drawn from the work of many researchers (e.g., Ames, 1992; Bandura, 1997; Deci \& Ryan, 1991; De Volder \& Lens, 1982; Hidi \& Renninger, 2006; Noddings, 1992; Wigfield \& Eccles, 2000; see Jones, 2009 for further explanation), the MUSIC model incorporates these ideas into one model and is a convenient way for practitioners to understand current research and theory in the field of motivation. Factor analyses have demonstrated that the MUSIC components are correlated, yet distinct factors in samples of undergraduate students (Jones \& Skaggs, 2016; Jones, Tendhar, \& Paretti, 2016), middle and high school students (Jones \& Wilkins, 2013; Parkes, Jones, \& Wilkins, 2015), and elementary school students (Jones \& Sigmon, 2016). In the sections that follow, we connect the elements of the Reggio Emilia Approach to the MUSIC model by discussing the components of the MUSIC model in order of empowerment, usefulness, success, interest, and caring. Then, we provide some implications for implementing the MUSIC model in preschool classes.

\section{Comparing the Reggio Emilia Approach to the MUSIC Model}

\section{An eMpowering Image of the Child}

The empowerment component of the MUSIC model refers to the amount of perceived control and decision making that students have over their learning (Jones, 2009). This component is consistent with the "autonomy" construct defined by Deci and Ryan (1991) as "people's strivings to be agentic, to feel like the 'origin' (deCharms, 1968) of their actions, and to have a voice or input in determining their own behavior" (p. 243). Teachers can empower students and support their autonomy by providing them with choices and allowing them to make decisions.

The Hundred Languages of Children is a primary text that outlines the predominant tenets and principles of the Reggio Emilia Approach and forms a basis for related study and practice. The title of this text also corresponds to a poem by the same name, written by Loris Malaguzzi, founder of the schools in Reggio. The beautiful and inspiring words of this poem describe for readers an image of a child that is strong, capable, competent, and yet who is often restricted by adults and the societies we have created. It describes the many possibilities for students who are provided opportunities to explore, to express themselves creatively, and who are empowered by their teachers and their learning environments. 
The child has a hundred languages...but they steal ninety-nine. The school and the culture separate the head from the body. They tell the child: to think without hands, to do without head, to listen and not to speak, to understand without joy, to love and to marvel only at Easter and at Christmas... And thus they tell the child that the hundred is not there. The child says: No way. The hundred is there. (Malaguzzi, 1993, p. vi)

In the Reggio Emilia Approach, learning environments are led by teachers who listen to children's ideas, who provide them with choices in the classroom and access to materials on a daily basis that give them a level of autonomy and the opportunity to explore independently. Teachers intentionally provide materials for students that will assist them in extending their ideas and the plans they have formulated based on their ideas. This approach is based on the belief that children must be active agents in the classroom in order for learning to occur and that students, when given range to participate in the learning process, "produce change and dynamic movement in the systems in which [they are] involved" (Rinaldi, 2006, p. 83). Students are defined as "powerful, active, competent protagonists of their own growth" (Edwards et al., 1998, p.180). Control in the classroom is viewed as a shared entity (p. 182); a balancing act where teacher and student listen to one another's point of view, work cooperatively to make use of available resources, share ideas and inspirations, and negotiate decisions within the learning process. Authors of literature on the curriculum in Reggio advocate for project work that provides students with opportunities to take leadership roles, to plan with group members, to make decisions, to delegate tasks, to share resources and ideas, and to develop a sense of ownership over the process (p. 33). All of these enhance student empowerment while also promoting motivation based on additional MUSIC model factors such as their perception of success, level of interest, and the usefulness of the project content. Figure 1 shows a child who has been provided with empowerment through her opportunity to design and construct a project model. 


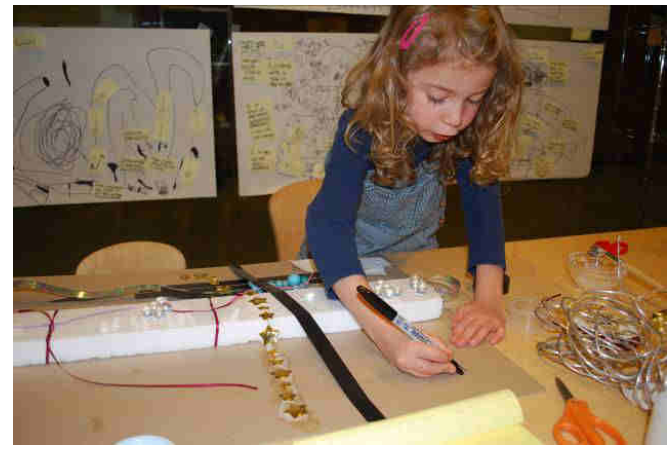

Figure 1. Student working in the studio space to construct a project model based on her original design and using a range of open-ended materials with the support of the studio teacher

\section{Projects With Usefulness, Authentic Meaning, and Value}

The usefulness component of the MUSIC model involves the extent to which students believe that the school work is useful for their short- or long-term goals (Jones, 2009). The importance of usefulness to students' motivation has been documented by researchers who study utility value (Eccles et al., 1983; Wigfield \& Eccles, 2000) and instrumentality (De Volder \& Lens, 1982; Kauffman \& Husman, 2004). One implication of the usefulness component is that teachers need to ensure that students understand the connection between school work and their goals. Another implication is to "provide opportunities for students to engage in activities that demonstrate the usefulness of the material in the real world" (Jones, 2009, p. 275).

Advocates of the Reggio Emilia Approach speak to curriculum design that is based upon exploratory investigation and project work. Projects not only provide children with the opportunity to make choices and negotiate decisions with teachers and peers (i.e., empower them), but also provide a meaningful and authentic context for learning because students can investigate real-world phenomena "that are worthy of their attention" (Edwards et al., 1998, p. 28). The role of teachers is to frame the project for the children so that they can envision the practical applications, including: raising questions that extend the process, providing materials that promote discovery of answers to their questions, providing necessary resources for students to overcome challenges they encounter along the way and to assist them in achieving their vision for the project, and providing them with the opportunity to apply their projectrelated knowledge in a real-world context (Edwards et al., 1998, p. 185). Rinaldi (2006) de- 
scribes the role of teachers by raising the following question for reflection throughout the course of these projects as well as daily curricular experiences: "How can we help children find the meaning of what they do, what they encounter, what they experience?" (p. 63). Thus, the teacher's role is consistent with the MUSIC model principle of usefulness.

\section{The Role of the Teacher in Scaffolding Success}

The success component of the MUSIC model is based on the idea that students need to believe that they can succeed if they put forth the appropriate effort (Jones, 2009). The success component was derived based on research related to competence motivation (Elliot \& Dweck, 2005; White, 1959), self-efficacy (Bandura, 1997), and expectancy for success (Eccles et al., 1983; Wigfield \& Eccles, 2000). Teachers can foster students' success beliefs in a variety of ways, including making expectations clear, providing opportunities for peers to work together on certain tasks and to scaffold one another, challenging students at an appropriate level (which includes the provision of developmentally appropriate materials and resources), and providing students with feedback regularly. The idea that teachers can affect students' motivation based upon the level to which they foster their success is also discussed by Rinaldi (2006) in literature describing the Reggio approach:

Children's competence and motivation can be either enhanced or inhibited depending on the...motivational force of the surrounding context. Numerous studies have brought to light the importance of the adult's role in young children's development... when the adults create educational contexts that enable children to utilize their own skills and competence. (p. 84)

Although it is important to create a learning environment that empowers students (as we discussed in a prior section), the role of the teacher remains vital and learning and motivation require a balance of teacher guidance and learner empowerment (Adams, 2006). Jones (2010b) also noted that empowerment and success are components that need to be balanced carefully; "too much of one or the other might hinder the other" (p. 11). On one hand, a student who has complete autonomy can have too many choices and not be motivated to choose any of them. On the other hand, a student who has no choices will feel constrained and not have her need for autonomy met. 
These ideas are consistent with Vygotskian principles that are important to Reggio Emilia Approaches. In the Reggio Emilia Approach, teacher scaffolding is implemented in a manner aligned with the tenets of Vygotsky's "zone of proximal development" (ZPD; Vygotsky, 1986, p. 188-189), which can promote increased competence and perceptions of success among students. The ZPD prescribes that student success will be higher when peers or teachers have provided a certain level of assistance that allows individual learners to extend their knowledge and skill further than they could alone. In other words, what students can accomplish in collaboration with others serves to both incorporate and transcend the individual learning process (Powell \& Kalina, 2009). According to the Reggio Emilia Approach, this environment is developed through the teacher's work to understand the needs of the children based on considerations of their prior knowledge, observation of the manner in which they manipulate materials, and documentation/analysis of the thought processes articulated and interests expressed by students during their investigation.

As an example, Figure 2 shows a child working on a number task using objects that were provided by a teacher. The teacher selected the paper with numbers and the objects based on her understanding of the child's ZPD in an attempt to allow the child to succeed at the task. When a task is too far beyond a child's ZPD, the child will not be motivated to continue the task because she will believe the task is impossible to complete. But when the task requires the child to use her competence in a manner that pushes her to learn more, yet be successful, the child will be motivated to persist at the task (Csikszentmihalyi, 1990).

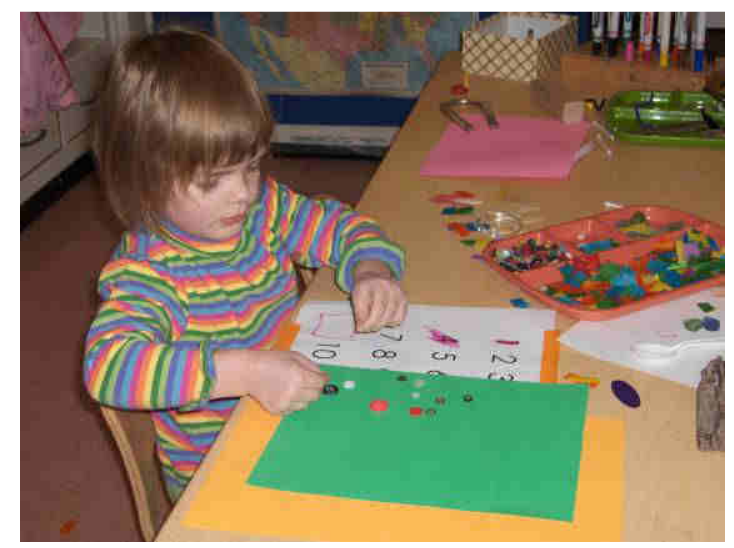

Figure 2. A child using teacher-provided resources 
Another approach to fostering students' success is to provide them with firsthand experiences that allow them to see their success (Bandura, 1997). One way that teachers using the Reggio Emilia Approach have shown students their successes is through the use of documentation panels. Documentation panels are often displayed throughout the hallways, classrooms, and outdoor learning environments in Reggio schools. Teachers create the documentation panels by filling them with photographs, student drawings, constructions, anecdotal notes, and teacher and child reflections on the learning process (see Figure 3).

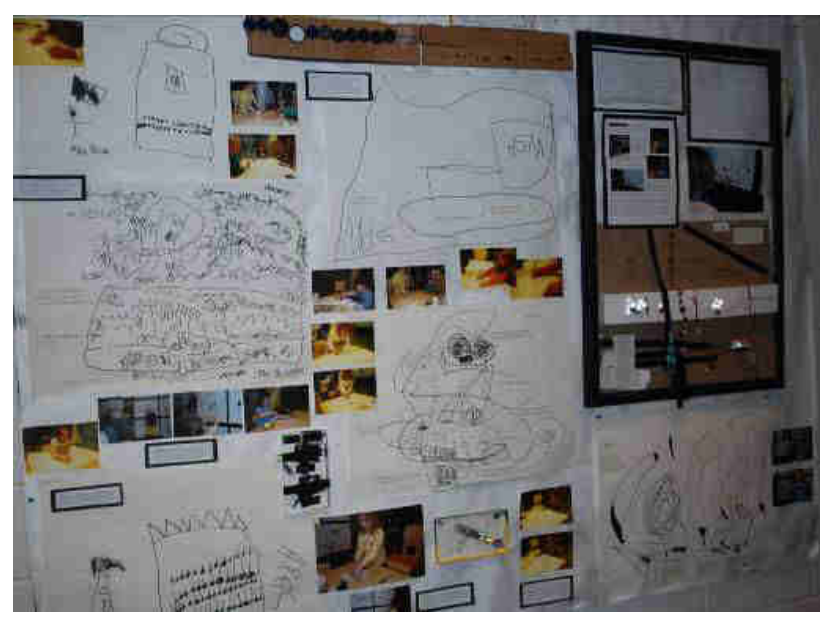

Figure 3. Documentation panels of children's original sketches and construction process.

In her book In Dialogue with Reggio Emilia, Rinaldi (2006) discusses the importance of documentation in providing a visual in which "The educational path becomes concretely visible" (p. 63). The visibility of the work allows students to see their success and to be reminded of it each time that they look at the documentation panels. As Gandini (2005) notes, "The elementary school does many things, but without documentation; nothing remains, only the written evaluations, but these say nothing about the learning paths the children followed..." (p. 63). The documentation panels, therefore, provide one means of showing and reminding students of their successes.

\section{Listening to the Interests of the Children}

Based on current theories of interest (e.g., Hidi \& Renninger, 2006), Jones (2009) explains that the interest component includes two theoretically distinct constructs: situational 
interest and individual interest. Situational interest refers to immediate, short-term enjoyment of instructional activities, whereas individual interest refers to internally activated personal values about a topic (Hidi \& Renninger, 2006). Teachers can create situational interest by designing instruction and school work that incorporate novelty, social interaction, games, humor, surprising information, and/or that engenders emotions (Bergin, 1999). Teachers can develop students' individual interest in a topic by providing opportunities for them to become more knowledgeable about the topic and by helping them understand its value (Hidi \& Renninger, 2006).

One of the ways Reggio-inspired teachers interest their students is through what is termed as "progettazione" or flexible planning (Edwards et al., 1998, p. 113). This flexible planning is achieved through continuous observation of the students' work, noting the questions students raise, facilitating meaningful discussions with the students as they engage in activities to determine points of inquiry, and, most importantly, reflecting on all observational data to design future learning investigations. Student interest is seen as the focal avenue for subsequent curriculum. Interests are described to include those verbally expressed by the children and those that teachers infer based on careful observation, meaningful inquiry, and professional expertise (Edwards et al., 1998, p. 113).

Jones (2009) explained that teachers can influence students' interest by introducing stimuli that promote student engagement, including the teacher demonstrating a positive attitude toward the content and being effective at describing the connections that exist between the content and students' personal interests. The role of the teacher in promoting enthusiasm for the content and helping children determine the best path for pursuing their questions can also raise students' interest. Interest and empowerment can also work together to foster students' motivation. As noted by Malaguzzi, “once children are helped to perceive themselves as authors or inventors, once they are helped to discover the pleasure of inquiry, their motivation and interest explode" (Edwards et al., 1998, p. 67). Teachers can contribute to the development of these perceptions by encouraging students to formulate designs stemming from their interests, to represent their ideas using open-ended materials based on their designs and to give them a forum for discussing their ideas with peers and teachers (see Figures 4 and 5). 

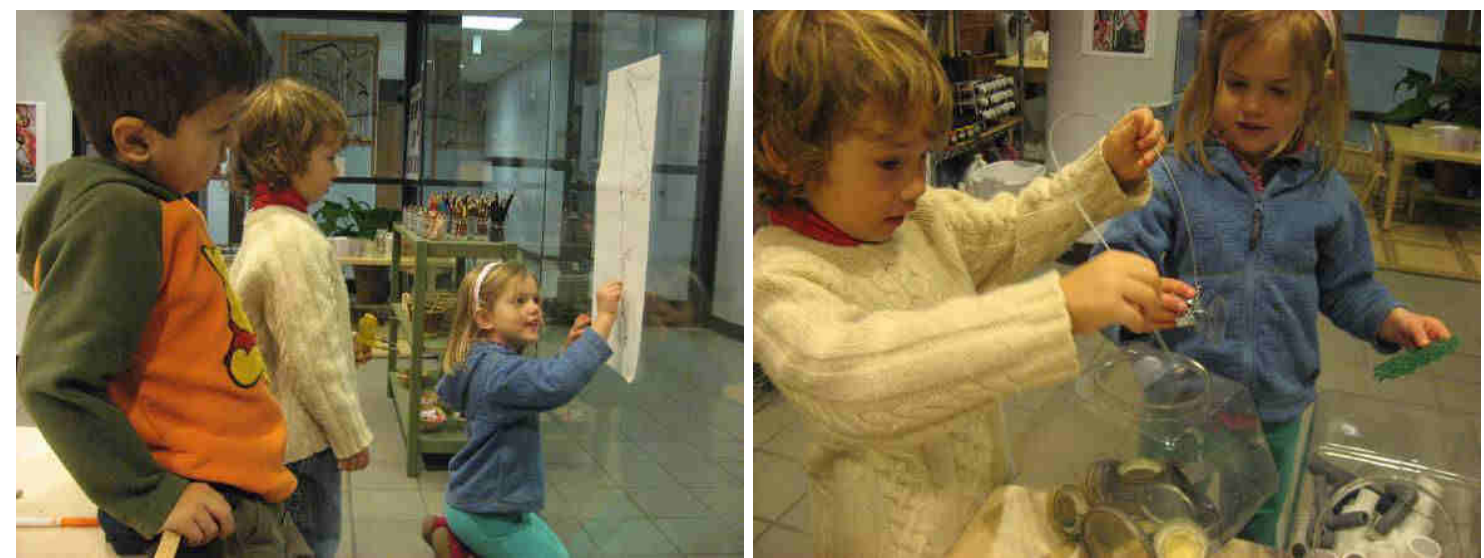

Figures 4 and 5. Students designing, building, and sharing their ideas with others

\section{A Teacher-Child Relationship Built on Mutual Caring}

The caring component of the MUSIC model includes two components: academic caring, associated with the degree to which students feel connected and supported in their school work and educational goals, and personal caring, associated with the degree to which students feel socially and personally connected and supported (Jones, 2009; Johnson, Johnson, \& Anderson, 1983). The caring component is consistent with constructs such as caring (Noddings, 1992), belongingness (Baumeister \& Leary, 1995), relatedness (Deci \& Ryan, 2000), and attachment (Ainsworth, 1973; Bowlby, 1969; for educational implications, see Bergin \& Bergin, 2009). To support academic caring, teachers can demonstrate that they care about whether students successfully meet the instructional objectives. To support personal caring, teachers can demonstrate that they care about students' general well-being and welfare.

The learning communities that define the schools of Reggio Emilia include the parents, children, teachers, and the larger community in which the school resides. Communities are designed to promote a sense of mutual caring amongst members and sustain feelings of relatedness, belongingness, "obligation to one another," and a commitment to a common goal (Hill, 2003, p. 8). When the children feel that all of these entities are invested in and care about their learning, the children should be more motivated in the classroom.

Within the classroom community, the schools of Reggio stress that "the teacher must establish a personal relationship with each child" (Edwards et al. 1998, p. 115), and they work to achieve this by placing children in classrooms with the same co-teaching team for three years (Edwards et al., 1998, p. 7). Caring communities are more easily fostered in this way, 
and over time, after engaging in multiple joint investigations and projects of shared interest, the students feel a sense of greater competence as a result of their understanding that they have the support of the other members of the community and that they can work through any challenges that arise alongside individuals who care about their success (Hill, 2003, p. 10). As is noted in The Hundred Languages of Children, "when adults communicate genuine and serious interest in the children's ideas and in their expressions of them, rich and complex work can result, even among very young children" (Edwards et al., 1998, p. 38).

\section{Examples of Integrating the MUSIC Model Components Into Instruction}

Thus far, we have primarily discussed the components of the MUSIC model as separate entities; however, any one element of instruction likely affects students' perceptions about more than one MUSIC component (Jones, 2009, 2015). Although it is useful conceptually to simplify motivation into one of the MUSIC model components, it is also important for teachers to understand how an instructional element can integrate multiple MUSIC components. The aim of this section is to provide some examples of this and to discuss how the examples might affect students' perceptions of several of the MUSIC model components. The examples were selected from two university-based preschools: one at South Dakota State's Fishback Center for Early Childhood Education in Brookings, South Dakota, and one on Virginia Tech's campus at the Virginia Tech Child Development Center for Learning and Research in Blacksburg, Virginia. Additionally we outline an example from a classroom at Loudoun Country Day School, a private, pre-K to eighth-grade school in Leesburg, Virginia.

\section{Hide and Seek Examples}

As we have noted, the Reggio Approach places value in long-term investigations and the opportunities they provide for children to explore in a more in-depth manner. At the Fishback Center at South Dakota State, teachers engaged children in a cross-curricular longterm investigation that incorporated social curricula, literacy skills, and math and social studies concepts. This investigation engaged children in a "hide and seek" type of game that spanned their campus and lasted many weeks (North American Reggia Emilia Alliance [NAREA], 2007). The project began from the simplest of observations by the classroom teacher who noticed the children using tubes in their play to make "elephant calls." The teacher noted that her observations of this play reminded her that they had a large stuffed an- 
imal elephant at the school named Ellie. This led her to pose a question to the children that sparked the long-term investigation: “...If you blow on those tubes...do you think an elephant would come to our classroom?" (NAREA, 2007, p. 1). As children considered this idea, their level of interest inspired teachers to help children embark upon a recurring elephant search and a back-and-forth communication system related to the elephant's whereabouts that included letters from parents who worked on the campus on which they reported spotting the elephant. These aspects helped to fuel the children's searches. Children engaged in hypothesizing and researching information related to elephants and habitats, mapping activities (both flat and 3-D maps), letter-writing, cultural connections, and making sense of fantasy versus reality (NAREA, 2007).

A similar project that was inspired by this investigation occurred at the Virginia Tech Child Development Center for Learning and Research (VT CDCLR) in which children continually searched for a missing Hokie Bird (the Virginia Tech mascot). This project incorporated many of the same types of processes as the one from the Fishback Center, including brainstorming Hokie Bird habitats, mapping his potential campus whereabouts, and then even working to design Hokie Bird traps.

These projects incorporated multiple aspects of both the Reggio Approach and the MUSIC model including but not limited to: curriculum driven by the interests of the children but framed by the expertise of the teacher (incorporates interest and scaffolding for success); building a sense of community that includes children, teachers, and families (incorporates caring); a focus on socially-based project work and long-term investigation opportunities (incorporates caring through the social aspect and interest and usefulness through the long-term aspects); investigation that allows the children to take an active role (incorporates empowerment); formulation of a real question and an actual goal within their work (demonstrated the usefulness of mapping, letter-writing, etc.); and a project created from an interest that derived directly from children's play. Practically speaking, this project at South Dakota State and the subsequent Hokie Bird investigation at Virginia Tech demonstrate that open-ended, inquirybased learning can be flexible with respect to the context and interests of the schools and classrooms in which they originate. 


\section{A Class Pet Example}

These very same principles of motivation and of the Reggio Emilia Approach can also be effectively implemented in classrooms within other school settings that may not directly adhere to the philosophies of Reggio Emilia. The next example we describe is from a Kindergarten classroom at the Loudoun Country Day School. The teacher in this classroom is inspired by many of the tenets we have discussed from the Reggio Emilia Approach, but implements them in a more "traditional" school. She works to incorporate inquiry-based practice and inspirations from Reggio into what she describes as a "traditional, but progressivelyindependent" classroom. While maintaining some components of a teacher-directed classroom, she finds ways to incorporate numerous opportunities for children to exhibit independence and autonomy. Aspects of motivation theory and the MUSIC model are highly apparent in the types of investigations she often designs for students. For example, to begin the school year, students have the opportunity to decide whether they would like a classroom pet, and if so, what type of pet. They begin by dividing into self-selected research groups representing the different potential animals that could serve as the class pet. The children are responsible for deciding which groups to form and join. Class time is built in explicitly for "Research Group" work but the teacher also allows spontaneous work on the project to occur during other parts of the day, such as during center time. She notes that the spontaneous project work often occurs when children are truly committed and engaged in the project. The children feel empowered by the opportunity to work through this process and to make decisions along the way. They are also motivated because they get to engage in a real task that has practical classroom applications (incorporates the usefulness component). The teacher acts as a facilitator during the research group work times by helping the children think through the important factors and necessary information to gather (incorporates the success component). In describing this process, the teacher notes the flexibility this project allows in regards to the children taking on different roles within the group that best align with their individual interests (e.g., reading information, leading group discussions, sketching, presenting). She also points out that the timeline for the project is flexible based on the level of interest the children show and that at the conclusion of the project each group presents their research findings prior to a deciding class vote.

This type of project offers numerous academic learning opportunities within science, social studies, mathematics, and literacy as well as important social collaboration experiences 
(incorporates the caring component). Children feel a legitimate sense of responsibility, as well as a sense of community as they work on a project with a common goal. Although this classroom is not housed in a philosophically, Reggio Emilia school, this teacher demonstrates how effectively a child-centered, inquiry-based project can be implemented in a way that is truly motivating for students.

\section{A Reflection on an Investigation Example}

Teachers at the VTCDCLR have used the form shown in Figure 6 to design instruction that is consistent with the MUSIC model. The VTCDCLR is a full-day, year-round, university-based preschool serving children age 15 months to 5 years old and is staffed by full-time, co-teaching pairs, part-time assistant teachers, and university undergraduate field study students. Teachers at the VTCDCLR use the "Reflection on an Investigation" form daily to help them in their planning (through the use of the "Title," "Why?" and "How" sections of the form) and in their reflection after the implementation of the curriculum (through the use of the "Reflection/Inspiration" section).

\section{$\underline{\text { Reflection on an Investigation }}$}

Title: What is the title of this investigation, project or provocation?

Why? Why have you chosen this set up? How does it relate to the current interests of the children and emerging curriculum?

How? What is the anticipated process/procedure or set up for carrying this out? How will this work?

What materials, resources and assistance will you need to gather? How will you facilitate and what questions will you ask?

Reflection/Inspiration: Who participated? How did the children manipulate/interact with the materials? What conversations were noted? What questions did the children have? What new ideas emerged from the children? What are your ideas/possibilities for future curriculum planning based on your observation and interpretation?

Figure 6. "Reflection on an Investigation" form developed at the Virginia Tech Child Development Center for Learning and Research, Blacksburg, VA

The components of the MUSIC model are evident in the questions raised by this document and require teachers to consider the components in their planning and reflection. For example, the question "How does it relate to the current interests of the children and emerging 
curriculum?" asks teachers to make an explicit connection between the curriculum and the children's interests. It also can trigger teacher to think about how the curriculum might be useful to children or to the real world. The question "How will you facilitate?" requires teachers to think about their role in supporting children's success. Two other MUSIC components that will likely be addressed with this question are (1) the amount of empowerment that they will provide the children (because it is based on how they facilitate) and (2) the amount of caring that they show through the manner in which they facilitate.

At the end of the investigations, teachers answer the questions in the "Reflection/Inspiration" section of the form. When teachers reflectively consider the answers to these questions they should be able to provide a learning environment that empowers students based on their needs and interests, that incorporates content the students will view as useful, that scaffolds success through provision of appropriate materials, resources, and assistance, that stimulates the interests of the students, and that inherently demonstrates to students that teachers care about their success in the classroom. This process allows them to consider the possibilities they may have missed or overlooked and gives them a chance to envision additional opportunities and extensions.

\section{Implications}

In this section, we provide some considerations for teachers to think about when designing instruction to intentionally motivate children using the MUSIC model.

1. Empowerment: The child's role in the learning process is vital and should be active rather than passive. Children should be provided opportunities to take ownership over aspects of their learning, to have a role in choosing topics for further investigation, to help select materials, and to raise new questions that can then be explored. This requires that teachers always look for opportunities for children to exhibit autonomy and to take on real responsibility in the classroom.

2. Empowerment, interest, and success: The environment is important in early childhood classrooms. The variety, type, and accessibility of materials in the classroom affect what children have the opportunity to learn. Learning will occur for children on a deeper level when materials are open-ended and provide for a variety of potential explorations. Teachers play a crucial role in providing materials that chal- 
lenge children in ways that allow them to be successful in their explorations. Also, it is important to provide materials to children on low and open shelves where they can access them independently and within times of free-play and open exploration.

3. Empowerment, success, and interest: The curriculum should be based on children's interests and framed by teacher expertise. Teachers consistently observe children and facilitate conversations with them related to their play and representational work to determine questions they have, areas in which they may have misconceptions, and topics that stem from play in which the children seem to continually engage. Teachers can then use their understanding of the developmental levels of the children in their classroom and provide appropriate materials that will allow the children to acquire more information and promote further exploration of these topics and questions. Additionally they can provide resources and set-up investigations to support areas where children may have misconceptions.

4. Interest, success, and caring: Children should have opportunities for sociallybased project work and investigations. These types of projects are developed from questions that children raise or ideas that they propose through their play in the classroom. Socially, working alongside peers provides learning related to teamwork, collaboration, delegating roles, providing constructive feedback to peers, and learning from the knowledge of others. These types of small group project opportunities allow children to gain knowledge that goes beyond surface level facts and supports a sense of community as children share a common goal with their peers and feel a sense of ownership and autonomy related to their project.

5. Usefulness, interest, and caring: The teacher's role should be multifaceted and include reflection, documentation, and action research. This includes teachers engaging in careful consideration of the experiences that have occurred in the classroom to document activities based on the meaning these experiences hold for the children in their classroom and to view themselves as researchers who have a daily window into the truest, most realistic, context of children's learning. Administrators can support teacher research by providing teacher work time, tools for documentation including cameras and computer access, and opportunities for teachers to dialogue with colleagues.

6. Caring and interest: There needs to be a sense of community within the classroom and school. This encompasses all of the relationships that are vital to children's success, both socially and academically. It begins when a child is first enrolled in a 
school and teachers and administrators work to get to know the family and the child and to provide opportunities for them to bring aspects of their own cultures, interests, and home lives into the experiences of the school. It is sustained through daily interactions between the teachers and families, development of mutual respect and common goals, and opportunities for parents to support curriculum and offer insights related to the learning process.

\section{Conclusion}

We provided evidence throughout the paper of how the Reggio Emilia Approach is consistent with current motivation research and theory. We found that the MUSIC Model of Motivation provided a useful lens through which to examine the Reggio approach because it focused our investigation on motivational components (i.e., empowerment, usefulness, success, interest, and caring) that have been determined to be critical to students' motivation (Jones, 2009, 2015). We conclude that the success of Reggio-inspired approaches is not by chance, but instead, is because the Reggio Emilia Approach fosters students' empowerment, promotes the usefulness of the content, facilitates students' success, ignites students' interest, and creates a caring environment that nurtures students' learning. In this type of environment, teachers choose to provide materials that are inviting and that allow children to bring shape to their ideas and to actively work towards answers to their questions alongside others. We believe that other early childhood educators should assess their own programs to determine whether they could do more to incorporate these motivational components into their educational environment, regardless of whether or not their program is entirely consistent with the Reggio Emilia Approach. Research and theory indicate that doing so can lead to motivated students who will then engage in more meaningful learning. We end with a quotation from Hill (2003), former director of curriculum at the VT CDCLR, whose explanation summarizes

nicely some of the outcomes of a Reggio-inspired school that are consistent with current motivation research and theory:

Participation in a community allows for learning to take place at multiple levels. The individual comes away with a strong sense of accomplishment, participation, membership, affiliation, self-esteem, power and control, support for ideas and the joy of participating in the process of bringing ideas to life. (p. 14) 


\section{Author Note}

Special thanks to all of the amazing teachers, children, and schools that inspired the projects we outlined here including: The Virginia Tech Child Development Center for Learning and Research, The Fishback Center for Early Childhood Education, Loudoun Country Day School, Jennifer Huggler Cross, Lynn Ann Wolf, Amanda Dodson Hayes, Jessica Cherebin, Karen Gallagher, Victoria Fu, Isabel Bradburn and Angie Cross. The authors have obtained photo releases from the parents of the featured children for all included photographs and examples of children's art or project work. 


\section{References}

Ainsworth, M. D. S. (1973). The development of infant-mother attachment. In B. Caldwell \& H. Ricciuti (Eds.), Review of child development research (Vol. 3, pp. 1-94). Chicago: University of Chicago Press.

Ames, C. (1992). Classrooms: Goals, structures, and student motivation. Journal of Educational Psychology, 84, 261-271. doi:10.1037/0022-0663.84.3.261

Adams, P. (2006). Exploring social constructivism: Theories and practicalities. Education, 34(3), 243-257.

Bandura, A. (1997). Self-efficacy: The exercise of control. New York: Freeman.

Baumeister, R., \& Leary, M. (1995). The need to belong: Desire for interpersonal attachments as a fundamental human motivation. Psychological Bulletin, 117, 497-529. doi:10.1037/0033-2909.117.3.497

Bergin, D. A. (1999). Influences on classroom interest. Educational Psychologist, 34, 87-98. doi:10.1207/s15326985ep3402_2

Bergin, C., \& Bergin, D. (2009). Attachment in the classroom. Educational Psychology Review, 21, 141-170. doi:10.1007/s10648-009-9104-0

Bowlby, J. (1969). Attachment (vol. I). New York: Basic.

Csikszentmihalyi, M. (1990). Flow: The psychology of optimal experience. New York: Harper \& Row.

deCharms, R. (1968). Personal causation: The internal affective determinants of behavior. New York: Academic Press.

Deci, E. L., \& Ryan, R. M. (1991). A motivational approach to self: Integration in personality. In R. Dienstbier (Ed.), Nebraska symposium on motivation (Vol. 38). Lincoln: University of Nebraska Press.

Deci, E. L., \& Ryan, R. M. (2000). The "what" and "why" of goal pursuits: Human needs and the self-determination of behavior. Psychological Inquiry, 11(4), 227-268. doi:10.1207/S15327965PLI1104_01

De Volder, M., \& Lens, W. (1982). Academic achievement and future time perspective as a cognitive-motivational concept. Journal of Personality and Social Psychology, 42(3), 566-57. doi:10.1037/0022-3514.42.3.566

Eccles, J. S., Adler, T. F., Futterman, R., Goff, S. B., Kaczala, C. M., Meece, J. L., \& Midgley, C. (1983). Expectancies, values, and academic behaviors. In J. T. Spence 
(Ed.), Achievement and achievement motivation (pp. 75-146). San Francisco, CA: Freeman.

Edwards, C., Gandini, L., \& Forman, G. (Eds.) (1998). The hundred languages of children: The Reggio Emilia approach-advanced reflections. $2^{\text {nd }}$ ed. Westport, CT: Ablex.

Elliot, A. J., \& Dweck, C. S. (2005). Competence and motivation: Competence as the core of achievement motivation. In A. J. Elliot, \& C. S. Dweck (Eds.), Handbook of competence and motivation (pp. 3-12). New York: Guilford.

Gandini, L. (2005). The essential voice of the teachers: Conversations from Reggio Emilia. In L. R. Williams (Ed.), In the spirit of the studio: Learning from the atelier of Reggio Emilia. New York, NY: Teachers College Press.

Hidi, S, \& Renninger, K. A. (2006). The four-phase model of interest development. Educational Psychologist, 41(2), 111-127. doi:10.1207/s15326985ep4102_4

Hill, L. (2003). Growing a community of place, friendship and mind. Innovations in Early Education, 10(1), 7-14.

Johnson, D.W., Johnson, R. T., \& Anderson, D. (1983). Social interdependence and classroom climate. Journal of Psychology, 114(1), 135-142. doi:10.1080/00223980.1983.9915406

Jones, B. D. (2009). Motivating students to engage in learning: The MUSIC Model of Academic Motivation. International Journal of Teaching and Learning in Higher Education, 21(2) 272-285.

Jones, B. D. (2010a). An examination of motivation model components in face-to-face and online instruction. Electronic Journal of Research in Educational Psychology, 8(3), 915-944.

Jones, B.D. (2010b, October). Strategies to implement a motivation model and increase student engagement. Paper presented at the annual meeting of the International Society for Exploring Teaching and Learning, Nashville, TN. Retrieved from http://www.MotivatingStudents.info

Jones, B. D. (2015). Motivating students by design: Practical strategies for professors. Charleston, SC: CreateSpace.

Jones, B. D., \& Sigmon, M. L. (2016). Validation evidence for the elementary school version of the MUSIC ${ }^{\circledR}$ Model of Academic Motivation Inventory. Electronic Journal of Research in Educational Psychology, 14(1), 155-174. Retrieved from.doi.org/10.14204/ejrep.38.15081. 
Jones, B. D., \& Skaggs, G. E. (2016). Measuring students' motivation: Validity evidence for the MUSIC Model of Academic Motivation Inventory. International Journal for the Scholarship of Teaching and Learning, 10(1). Retrieved from http://digitalcommons.georgiasouthern.edu/ij-sotl/vol10/iss1/7

Jones, B. D., Tendhar, C., \& Paretti, M. C. (2015). The effects of students' course perceptions on their domain identification, motivational beliefs, and goals. Journal of Career Development. Advance online publication. doi:10.1177/0894845315603821

Jones, B. D., \& Wilkins, J. L. M. (2013, May). Validity evidence for the use of a motivation inventory with middle school students. Poster presented at the annual meeting of the Society for the Study of Motivation, Washington, D.C.

Kauffman, D. F., \& Husman, J. (2004). Effects of time perspective on student motivation: Introduction to a special issue. Educational Psychology Review, 16(1), 1-7. doi:10.1023/B:EDPR.0000012342.37854.58

Malaguzzi, L. (1993). No way. The hundred is there. In C. Edwards, L. Gandini, \& G. Forman (Eds.), The hundred languages of children: The Reggio Emilia approach to early childhood education. (p. vi). Norwood, NJ: Ablex Publishing.

Noddings, N. (1992). The challenge to care in schools: An alternative approach to education. New York: Teachers College Press.

North American Reggio Emilia Alliance (2007). Ellie: Who are you? Where did you come from? Brookings, SD: Fishback Center for Early Childhood Education. Retrieved from http://www.reggioalliance.org/members_area/experience/ellie/index.php

Parkes, K., Jones, B. D., \& Wilkins, J. (2015). Assessing music students' motivation using the MUSIC Model of Academic Motivation Inventory. UPDATE: Applications of Research in Music Education. Advance online publication. doi:10.1177/8755123315620835

Powell, K. C., \& Kalina, C. J. (2009). Cognitive and social constructivism: Developing tools for an effective classroom. Education, 130(2), 241-250.

Rinaldi, C. (2006). In dialogue with Reggio Emilia: Listening, researching and learning. London and New York: Routledge. doi:10.4324/9780203317730

Vygotsky, L. (1986). Thought and Language. A. Kozulin, (Ed.). Cambridge, MA: The MIT Press.

White, R. W. (1959). Motivation reconsidered: The concept of competence. Psychological Review, 66(5), 297-333. doi:10.1037/h0040934 
Wigfield, A., \& Eccles, J. S. (2000). Expectancy-value theory of achievement motivation. Contemporary Educational Psychology, 25, 68-81. doi:10.1006/ceps.1999.1015 